\title{
Supplementary effect of Sweet Potato (Ipomoea batatas) Silage on Growth Performance and Carcass Traits of Local Lambs Grazing Natural Pasture in Tembaro District, Southern Ethiopia
}

\author{
Tegene Negesse ${ }^{1}$, Gebremariam Gebremichael ${ }^{2}$, Mohammed Beyan ${ }^{3}$ \\ ${ }^{1,3}$ Hawassa University, School of Animal and Range Sciences,P. O. Box 05, Hawassa, Ethiopia. \\ ${ }^{2}$ Mizan-Tepi University, Department of Animal Science, P.O.Box 260, Mizan-Teferi, Ethiopia
}

\begin{abstract}
Effect of supplementing Hawassi-83 sweet potato silage (SPS) containing $70 \%$ vine and $30 \%$ tuber on growth performance and carcass traits of grazing lambs were evaluated through on-farm feeding trial in Tembaro district, SNNPR, Ethiopia. Treatment diets formulated were: $T 1=$ grazing alone; $T 2, T 3$ and T4 were grazing plus SPS supplemented (DM basis) at 1, 2 and 4\% of lamb's body weight, respectively. At the age of 120 days after planting, vine cuttings were harvested at $3 \mathrm{~cm}$ above the ground and wilted under sunlight for $12 \mathrm{hrs}$. The tubers and vines were then chopped and mixed at the ratio of 70\%:30\% ( vine:tuber) and put in an air tight linen sack lined with plastic sheet, compacted with wooden stick, tightened with a rope and covered with plastic sheet to ensure anaerobic fermentation and ensiled for 30 days. Samples of natural pasture (NP) from the grazing area were harvested at the beginning and end of the trial. Five lambs (5-6 month-old; $14.3 \pm 0.5 \mathrm{~kg}$ ) were randomly assigned to each of the four treatment diets and fed for 84 days. Crude protein content of SPS was $14.07 \%$ and that of the $N P$ at the beginning and end of the trial were 10.73 and $8.13 \%$, respectively; and in-vitro DM digestibility of SPS was $84.74 \%$ and that of NP at the beginning and end of the trial were 65.4 and $51.77 \%$, respectively. The DM intakes of lambs significantly $(p<0.05)$ increased from 151.4 to $620.2 \mathrm{~g} / \mathrm{head} / \mathrm{d}$ as the level of supplementation increased from $T 2$ to T4. Average daily body weight gain (36.7, 60.5, 87.1 and $119.5 \mathrm{~g} / \mathrm{head} / \mathrm{d})$ among treatments $(T 1<T 2<T 3<T 4)$ were significantly different $(P<0.05)$. Higher $(P<0.05)$ slaughter $(23.3 \mathrm{~kg})$ and hot carcass weights $(11.5 \mathrm{~kg})$ and thus higher dressing percentage (49.4\%) were obtained from T4 than those of the other treatments. As the level of SPS supplementation increased body weight gain and dressing percentage improved. Therefore, supplementing local lambs that are grazing the $N P$ with sweet potato silage up to $4 \%$ of body weight (DM basis) is recommended.
\end{abstract}

Keywords- Sweet Potato Silage, Grazing lambs, Supplementation, Carcass traits.

\section{INTRODUCTION}

Ethiopia's livestock population is believed to be the largest in Africa. The sector has a significant contribution to the country's economy, and is still expected to support its economic development (CSA, 2013). However, the contribution of the sector at either macro or micro level is below its potential (Solomon et al., 2010) and the performance of the animals is poor because of different factors of which feed shortage is a major one. Sweet potato is important due to its' potential as livestock feed. The vines contain high levels of crude protein, high dry matter content and can form a major source of quality animal feed. Moreover, silages with ratios of 30 to $70 \%$ of roots and vines resulted in good quality products that could be stored for at least 3 months (Giang et al., 2004). Supplementing of sweet potato vine could have a potential as energy, protein, vitamins and mineral supplement for ruminant animals. However, there is scanty of information regarding the effect of sweet potato silage supplementing on growth performance and carcass traits of lambs in Ethiopia.

This study therefore, was intended to evaluate the effect of sweet potato silage supplementing on nutrient intake, growth performance and carcass traits of grazing lambs.

\section{MATERIALS AND METHOD}

Description of the study area

The study was conducted in Tembaro District, which is found in South Nation Nationalities and Peoples Regional State (SNNPRS), Ethiopia. It is located at about $410 \mathrm{~km}$ and $180 \mathrm{~km}$ south of Addis Ababa and south west of Hawassa, respectively. Geographically, it is located between $32^{\circ} 98^{\prime} \mathrm{E}$ to $34^{0} 29^{\prime} \mathrm{E}$ latitude and $8^{0} 08^{\prime} \mathrm{N}$ to $8^{0} 9^{\prime} \mathrm{N}$ longitude. The total area of the District is about 27,917 hectares.

Preparation of silage

Sweet potato variety called Hawassi-83 was selected over the other varieties because it is available in the study district and is early maturing. Then, the vines were purchased from the farmer training center of the selected Kebele and supplied to the participant households $(\mathrm{HH})$. Each $\mathrm{HH}$ planted on 0.45 ha of land in August 2012. Spacing between 
rows was $60 \mathrm{~cm}$ and between plants $30 \mathrm{~cm}$. Planting, weeding and harvesting were uniformly done by the selected HHs under the follow-up of the researcher. The vine was cut 120 days after planting at $3 \mathrm{~cm}$ above ground manually using sickle. After one day, the tuber was dug out by fork and dirty materials removed manually by hand. The sweet potato vines were chopped according to the suggestion of Giang et al (2004) to a size of about $2-5 \mathrm{~cm}$ and wilted under the sun for 12 hours and turned 10 times per day. The dry matter at ensiling was about 30\%-35\%. The process of ensiling was carried out according to the method suggested by Kung and Shaver (2001).

Sweet potato tubers used were washed with tap water to remove sands and sliced manually using knife into small pieces (about $1 \mathrm{~cm}$ ) and the chopped vine and tuber were weighed and mixed on the plastic sheet properly at the ratio of 70\%:30\% vine to tuber on fresh basis, according to the recommendation of Stathers et al. (2005). Finally, the mixture was put in the impermeable sack lined inside with plastic sheet and compacted with wooden stick. The sack was tightened with rope fiber and covered with strong plastic in order to ensure the anaerobic fermentation and put above the ground in order to reduce over fermentation leading to heat development. Then, the material was considered ready for use after 30 days of ensiling.

\section{Experimental design and treatment diets used during} the feeding trial

Twenty ram lambs (5-6 months old with pre-trial body weight of $14.3 \pm 0.5 \mathrm{~kg}$ ) were purchased from the local market. Before starting the experiment, the lambs were treated for external and internal parasites using acaricides and albendazole, respectively. The experiment was conducted in a completely randomized design (CRD) with four treatments and five animals per treatment.

\section{On-farm feeding trial}

The dry matter of the sweet potato silage was determined before starting the actual feeding trial. Every day a measured amount of silage was supplemented to the experimental lambs after they returned from the grazing area at 17:00 hr. The amount supplemented was adjusted every 14 days with the corresponding live weight change of the lambs.

One household was selected purposely for the onfarm feeding trial. The above mentioned twenty ram lambs were randomly assigned five rams for each of the four treatment diets. The ram lambs were housed in individual pens provided with feeding and watering troughs. Clean water was supplied free of choice. After 14 days of adaptation period to allow adjustment of the lambs to the diets, pens and other management conditions, the actual data collection period lasted for 84 days. Feed was offered at 17:00h and refused weighed in the morning at 8:00h. The lambs were weighed using spring balance at the beginning and end and every two weeks during the trial period. The feed conversion ratio (FCR) was calculated by dividing the dry matter intake with the daily weight gain.

Evaluation of carcass traits

At the end of the feeding trial, three lambs from each treatment were randomly selected. The lambs were fasted over night, weighed and then killed by severing the jugular vein and the carotid artery with knife following standard slaughter procedures (Abdullah et al., 1998). The bodies were skinned; the heads and feet were removed. Then, carcasses were eviscerated and the internal organs and carcass were weighed by a digital balance. The hot carcass weight was weighed after removing of the head, thorax, abdominal and pelvic cavity contents as well as legs below the hock and knee joints. Dressing percentage was then calculated using the formula $=$ (hot carcass weight/slaughter body weight) x100. Some components of edible (kidneys, liver with bile, heart) and non-edible offal's (lungs with trachea, testis and spleen) were weighed separately and not included in dressed carcass. The carcass was divided in to four primal cuts (leg, loins, rack and shoulder) according to Abdullah et al. (1998) and weighed separately.

In- vitro dry matter digestibility

In-vitro dry matter digestibility (IVDMD) of feed samples was determined by ANKOM Technology- DAISY ${ }^{\text {II }}$ Incubator. After samples were dried and ground to pass through $1 \mathrm{~mm}$ sieve size about $0.25 \mathrm{~g}$ was weighed in to ANKOM Filter bag (Ankom ${ }^{\circledR}$ Technology, \# F57) and then incubated in the ANKOM jars containing rumen fluid and medium mixture (solution $\mathrm{A}$ and $\mathrm{B}$ ) for 48 hours. The rumen fluid was collected from two fistulated sheep fed twice a day with a diet of grass hay and concentrate based on their daily requirements and water was provided adlibitum. After incubating for $48 \mathrm{hrs}$, the filter bags were removed and washed with tap water until they were clear, soaked with acetone and then further extracted with neutral detergent solution in the $\mathrm{ANKOM}^{200}$ fiber analyzer.

\section{Chemical analysis}

Absolute dry matter (DM) and ash contents of the samples (sweet potato silage and natural pasture) were determined according to AOAC (1990) while the total nitrogen $(\mathrm{N})$ was determined by the Kjeldhal method (AOAC, 1990) and crude protein $(\mathrm{CP})$ was calculated as $\mathrm{N} \times 6.25$. The neutral detergent fiber (NDF), acid detergent fiber (ADF) and acid detergent lignin (ADL) were determined using the ANKOM Technology method developed by Van Soest et al. (1991). Metabolizable energy (ME) was estimated according to the model: $M E(M J / k g D M)=13.5-0.15 * A D F \%+0.14 * C P \%$ $-0.15 * A s h \%$ (MAFF 1984; cited in Etela et al., 2008).

Data management and statistical analysis

Multivariate ANOVA was conducted on body weight changes, nutrient intake and carcass parameter using General Linear Model (GLM) procedure of SPSS soft ware, version 20.0. Means were separated using Duncan's multiple range test at $p<0.05$. The model used for this analysis was $Y i j=\mu+T i+e i j$; where: $Y i j=$ response variable 
(body weight gain, carcass parameters, nutrient intake); $\mu=$ over all mean; $T i=$ Treatment effect (level of sweet potato silage supplementation); eij= random error.

\section{RESULTS}

Chemical composition and in-vitro dry matter digestibility

The results of chemical composition and in-vitro dry matter digestibility (IVDMD) of sweet potato silage and natural

Table 1: Chemical composition and in-vitro DM digestibility of sweet potato silage and natural pasture (Mean \pm SE)

\begin{tabular}{lccc}
\hline \multirow{2}{*}{ Parameters } & Sweet potato silage & Beginning of trial & End of trial \\
\cline { 3 - 4 } & & $40.01 \pm 0.13^{\mathrm{b}}$ & $88.33 \pm 0.65^{\mathrm{a}}$ \\
Dry matter (\%) & $24.05 \pm 0.15$ & $91.35 \pm 0.38$ & $90.58 \pm 0.26$ \\
Organic matter (\%DM) & $91.39 \pm 0.59$ & $8.65 \pm 0.38$ & $9.42 \pm 0.26$ \\
Ash (\%DM) & $8.61 \pm 0.59$ & $10.73 \pm 0.20^{\mathrm{a}}$ & $8.13 \pm 0.12^{\mathrm{b}}$ \\
Crude protein (\%DM) & $14.07 \pm 0.08$ & $68.05 \pm 0.69^{\mathrm{b}}$ & $70.73 \pm 0.34^{\mathrm{a}}$ \\
Neutral detergent fiber (\%DM) & $24.08 \pm 0.10$ & $30.42 \pm 0.29$ & $29.83 \pm 0.23$ \\
Acid detergent fiber (\%DM) & $14.48 \pm 0.28$ & $14.77 \pm 0.24^{\mathrm{b}}$ & $16.53 \pm 0.31^{\mathrm{a}}$ \\
Acid detergent lignin (\%DM) & $2.99 \pm 0.12$ & $8.52 \pm 0.10^{\mathrm{a}}$ & $6.31 \pm 0.14^{\mathrm{b}}$ \\
Metabolizable energy (MJ/ kg DM) & $12.01 \pm 0.05$ & $65.40 \pm 0.27^{\mathrm{a}}$ & $51.77 \pm 0.40^{\mathrm{b}}$ \\
In vitro dry matter digestibility (\%) & $84.74 \pm 0.30$ & & \\
\hline
\end{tabular}

Mean values in the same row differ significantly $(P<0.05)$; DM=dry matter

\section{Nutrient intake of the experimental lambs}

The results of dry matter and nutrient intakes of the experimental lambs are summarized in Table 2. The intake of DM, OM, CP NDF, ADF, ADL and ME significantly $(p<0.05)$ differed among the three treatments and increased with the increasing supplementary level of sweet potato silage. Among all treatment groups the nutrient intake of the lambs fed $\mathrm{T} 2$ was the lowest and $\mathrm{T} 4$ the highest $(\mathrm{P}<0.05)$ while those fed on $\mathrm{T} 3$ diet were in between.

Table 2: Nutrient intake of grazing lambs supplemented with four levels of sweet potato silage

\begin{tabular}{|c|c|c|c|c|c|c|}
\hline \multirow[b]{2}{*}{ Nutrient intake } & \multicolumn{4}{|c|}{ Treatment diets } & \multirow[b]{2}{*}{$\mathrm{SE}$} & \multirow[b]{2}{*}{ P-value } \\
\hline & $\mathrm{T} 1$ & $\mathrm{~T} 2$ & $\mathrm{~T} 3$ & $\mathrm{~T} 4$ & & \\
\hline Dry matter (g/head/d) & - & $151.4^{\mathrm{c}}$ & $321.6^{\mathrm{b}}$ & $620.2^{\mathrm{a}}$ & 1.12 & $<0.001$ \\
\hline Organic matter (g/head/d) & - & $138.4^{\mathrm{c}}$ & $293.9^{b}$ & $566.8^{\mathrm{a}}$ & 1.02 & $<0.001$ \\
\hline Crude protein $(\mathrm{g} / \mathrm{head} / \mathrm{d})$ & - & $21.3^{\mathrm{c}}$ & $45.3^{\mathrm{b}}$ & $87.3^{\mathrm{a}}$ & 0.16 & $<0.001$ \\
\hline Neutral detergent fiber $(\mathrm{g} / \mathrm{head} / \mathrm{d})$ & - & $36.5^{\mathrm{c}}$ & $77.4^{\mathrm{b}}$ & $149.3^{\mathrm{a}}$ & 0.27 & $<0.001$ \\
\hline Acid detergent fiber $(\mathrm{g} / \mathrm{head} / \mathrm{d})$ & - & $21.9^{\mathrm{c}}$ & $46.6^{\mathrm{b}}$ & $89.8^{\mathrm{a}}$ & 0.16 & $<0.001$ \\
\hline Acid detergent lignin (g/head/d) & - & $4.5^{\mathrm{c}}$ & $9.6^{\mathrm{b}}$ & $18.5^{\mathrm{a}}$ & 0.03 & $<0.001$ \\
\hline Metabolizable energy $(\mathrm{MJ} / \mathrm{head} / \mathrm{d})$ & - & $1.8^{\mathrm{c}}$ & $3.9^{\mathrm{b}}$ & $7.5^{\mathrm{a}}$ & 0.01 & $<0.001$ \\
\hline
\end{tabular}

$a b c$ Mean values in the same row differ significantly $(P<0.05)$, SE=standard error.

The lambs under $\mathrm{T} 2$ groups had FCR $(\mathrm{P}<0.05)$ better than the other supplemented groups and T3 was also better than T4. There was a decreasing trend in FCR with increasing level of supplementation.

The trend in body weight gain (BWG) of the grazing lambs supplemented with four levels of sweet potato silage is
Growth performance and feed conversion ratio of the lambs

The results of body weights, average daily weight gain (ADG) and feed conversion ratio (FCR) are presented in Table 3. The highest final body weight, total weight gain and ADG $(\mathrm{P}<0.05)$ was obtained from lambs supplemented with T4 while the un-supplemented (T1) had the lowest but those fed on $\mathrm{T} 2$ and $\mathrm{T} 3$ were in between. pasture are presented in Table 1. The DM, NDF and ADL of the pasture, mainly grasses, were significantly of trial while OM, ash and ADF showed no differences $(\mathrm{P}>0.05)$ throughout the trial. 
Table 3: Growth performance and feed conversion ratio of grazing lambs supplemented with four levels of sweet potato silage

\begin{tabular}{lcccccc}
\hline \multirow{2}{*}{ Parameter } & \multicolumn{7}{c}{ Treatment diets } & & \\
\cline { 2 - 5 } & $\mathrm{T} 1$ & $\mathrm{~T} 2$ & $\mathrm{~T} 3$ & $\mathrm{~T} 4$ & SE & P-value \\
\hline Initial body weight $(\mathrm{kg})$ & 14.26 & 14.3 & 14.36 & 14.28 & 0.24 & 0.992 \\
Final body weight $(\mathrm{kg})$ & $17.34^{\mathrm{d}}$ & $19.38^{\mathrm{c}}$ & $21.68^{\mathrm{b}}$ & $24.32^{\mathrm{a}}$ & 0.18 & $<0.001$ \\
Total body weight gain $(\mathrm{kg})$ & $3.08^{\mathrm{d}}$ & $5.08^{\mathrm{c}}$ & $7.32^{\mathrm{b}}$ & $10.04^{\mathrm{a}}$ & 0.31 & $<0.001$ \\
Average daily gain $(\mathrm{g} / \mathrm{head})$ & $36.7^{\mathrm{d}}$ & $60.5^{\mathrm{c}}$ & $87.1^{\mathrm{b}}$ & $119.5^{\mathrm{a}}$ & 3.73 & $<0.001$ \\
FCR (g DMI/g of gain) & - & $2.54^{\mathrm{c}}$ & $3.73^{\mathrm{b}}$ & $5.22^{\mathrm{a}}$ & 0.18 & $<0.001$ \\
\hline
\end{tabular}

Means in a row with different superscripts are different $(p<0.05) ; F C R=$ feed conversion ratio; $S E=$ standard error

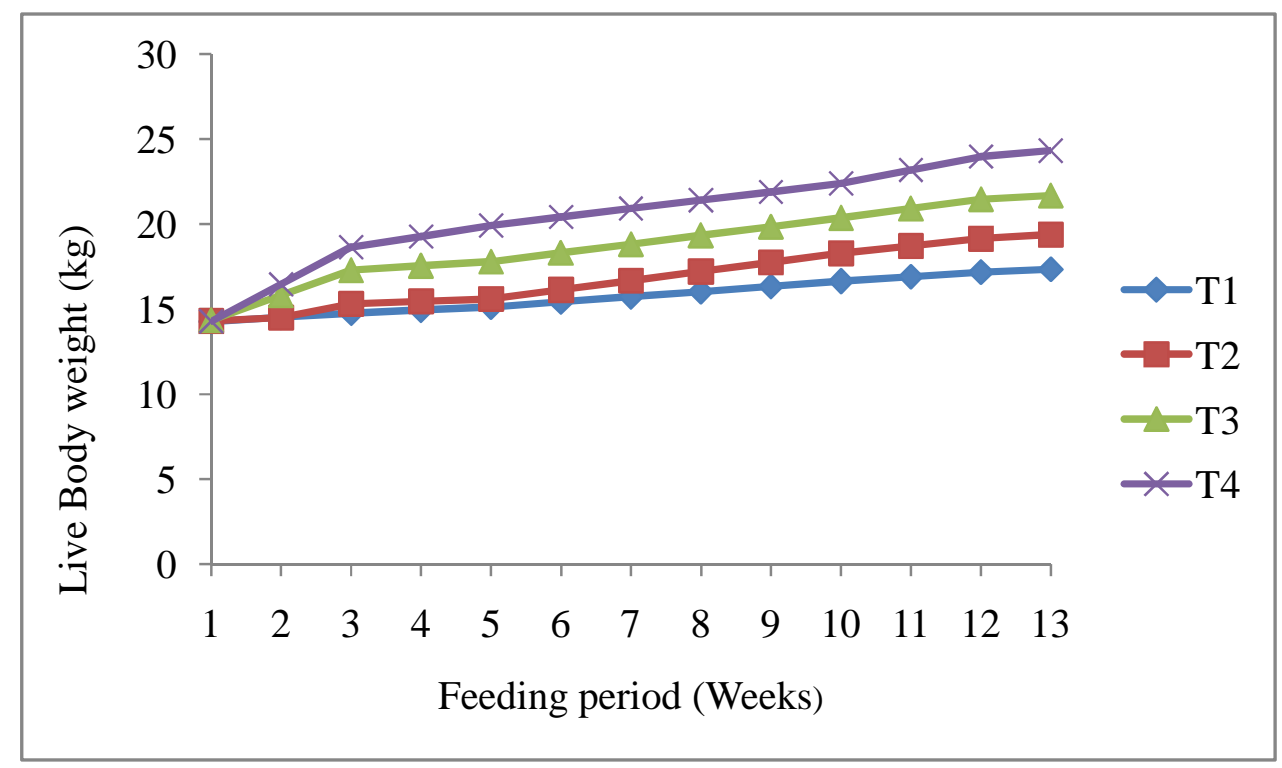

Fig.1: Trend of weight gain of the experimental lambs during the feeding trial

Carcass traits of the lambs

As shown in Table 4, the average slaughter body weight, hot carcass weight, dressing percentage, weights of shoulder and neck, rack, loin and leg showed significant
$(\mathrm{P}<0.05)$ differences among treatment diets. The highest values were obtained from lambs fed on $\mathrm{T} 4$ and lowest from those on $\mathrm{T} 1$ while lambs on $\mathrm{T} 2$ and $\mathrm{T} 3$ were in between.

Table 4: Slaughter body weight, hot carcass weight, dressing percentage and primal cuts of grazing lambs supplemented with four levels of sweet potato silage

\begin{tabular}{|c|c|c|c|c|c|c|}
\hline \multirow{2}{*}{ Parameters } & \multicolumn{4}{|c|}{ Treatment diets } & \multirow[b]{2}{*}{ SE } & \multirow[b]{2}{*}{ P-value } \\
\hline & $\mathrm{T} 1$ & $\mathrm{~T} 2$ & $\mathrm{~T} 3$ & $\mathrm{~T} 4$ & & \\
\hline Slaughter body weight $(\mathrm{kg})$ & $16.7^{\mathrm{d}}$ & $18.6^{\mathrm{c}}$ & $20.6^{\mathrm{b}}$ & $23.3^{\mathrm{a}}$ & 0.25 & $<0.001$ \\
\hline Hot carcass weight $(\mathrm{kg})$ & $7.4^{\mathrm{d}}$ & $8.5^{\mathrm{c}}$ & $9.8^{\mathrm{b}}$ & $11.5^{\mathrm{a}}$ & 0.15 & $<0.001$ \\
\hline $\begin{array}{l}\text { Dressing percentage }(\%) \\
\text { Primal cuts of the carcass }(\mathrm{kg})\end{array}$ & $44.2^{\mathrm{d}}$ & $45.7^{\mathrm{c}}$ & $47.4^{\mathrm{b}}$ & $49.4^{\mathrm{a}}$ & 0.27 & $<0.001$ \\
\hline Shoulder and neck weights & $3.1^{\mathrm{d}}$ & $3.4^{\mathrm{c}}$ & $3.8^{\mathrm{b}}$ & $4.3^{\mathrm{a}}$ & 0.06 & $<0.001$ \\
\hline Rack weights & $0.7^{\mathrm{d}}$ & $0.8^{\mathrm{c}}$ & $0.9^{\mathrm{b}}$ & $1.0^{\mathrm{a}}$ & 0.01 & $<0.001$ \\
\hline Loin weights & $0.8^{\mathrm{d}}$ & $0.9^{\mathrm{c}}$ & $1.0^{\mathrm{b}}$ & $1.2^{\mathrm{a}}$ & 0.03 & $<0.001$ \\
\hline Leg weights & $2.8^{\mathrm{d}}$ & $3.1^{\mathrm{c}}$ & $3.4^{\mathrm{b}}$ & $3.9^{\mathrm{a}}$ & 0.05 & $<0.001$ \\
\hline
\end{tabular}




\section{Edible and non-edible offal of the lambs}

In the present study, weight of heart, kidney, liver, testis, lungs with trachea and spleen are summarized Table 5.The highest $(p<0.05)$ weights of Liver, kidney, lungs with trachea and spleen were from lambs supplemented with T4 and the lowest from those on T1 while those on T2 and T3 were in between. The testis weight were significantly $(\mathrm{P}<0.05)$ differenct between the supplemented and unsupplemented groups. However, differences were not significant $(\mathrm{P}>0.05)$ among supplemented groups. The heart weights were not significantly $(\mathrm{p}>0.05)$ different among experimental groups.

Table 5: Edible and non-edible offal of grazing lambs supplementing with four levels of sweet potato silage

\begin{tabular}{|c|c|c|c|c|c|c|}
\hline \multirow{2}{*}{ Parameters } & \multicolumn{4}{|c|}{ Treatment diets } & \multirow[b]{2}{*}{ SE } & \multirow[b]{2}{*}{$\mathrm{P}$-value } \\
\hline & $\mathrm{T} 1$ & $\mathrm{~T} 2$ & T3 & $\mathrm{T} 4$ & & \\
\hline \multicolumn{7}{|l|}{ Edible offal (g) } \\
\hline Heart & 70.8 & 71 & 71.2 & 71.5 & 0.33 & 0.467 \\
\hline Liver & $248^{\mathrm{d}}$ & $275^{\mathrm{c}}$ & $305^{\mathrm{b}}$ & $345^{\mathrm{a}}$ & 3.63 & $<0.001$ \\
\hline Kidney & $48.5^{\mathrm{d}}$ & $53.9^{\mathrm{c}}$ & $59.7^{\mathrm{b}}$ & $67.5^{\mathrm{a}}$ & 0.71 & $<0.001$ \\
\hline Testis & $42.5^{\mathrm{b}}$ & $53.6^{\mathrm{a}}$ & $54.0^{\mathrm{a}}$ & $54.9^{\mathrm{a}}$ & 0.65 & $<0.001$ \\
\hline \multicolumn{7}{|l|}{ Non-edible offal $(\mathrm{g})$} \\
\hline Spleen & $30.9^{\mathrm{d}}$ & $34.4^{\mathrm{c}}$ & $38.1^{\mathrm{b}}$ & $43.4^{\mathrm{a}}$ & 0.46 & $<0.001$ \\
\hline Lungs with trachea & $235^{\mathrm{d}}$ & $262^{c}$ & $290^{\mathrm{b}}$ & $328^{a}$ & 3.46 & $<0.001$ \\
\hline
\end{tabular}

\section{DISCUSSION}

Chemical composition and in vitro dry matter digestibility of sweet potato silage and natural pasture The dry matter (DM) content of the silage (Table 1) in this study was higher than the values (15.1-15.4\%) reported by Giang et al (2004); may be due to differences in stage of maturity leading to differences in DM content of the material at the time of ensiling, duration of ensiling and the ratio of the tubers and vines in the silages. The results of the DM content of this silage was also slightly higher than earlier reports $(20.9,20.8,22.9,22.0 \%$ DM for Belela, Temesgen, Beletech and Tula varieties, respectively) ensiled at 30:70 ratio of sweet potato root to vine (Gebregziabher, 2013). However, the present findings were, lower than the value $(32.8 \%)$ reported by An et al. (2004). The differences may be attributed to absence or presence of root in the silages. The DM content of the silage is also affected by variety which agrees with the findings of Giang et al. (2004).

The crude protein (CP) content of the sweet potato silages were higher than the values $(6.5-9.38 \%)$ reported by Vellaikumar (2006); and only slightly higher than the figures (10.9-13.9\%) presented by Gebregziabher (2013). The CP content in the present study was comparable with the value (13.0\%) reported by Giang et al. (2004). However, the CP content as assessed in this study was lower $(23.4 \%)$ than that reported by An et al. (2004). The differences as observed among the different studies may have been attributed to the ratio of tubers to vines (as CP content and the ratio of vine to tuber are inversely related), varietal differences, and factors such as ensiling time. Gebregziabher (2013) also reported that if the amount of tubers were increased there was a fall in $\mathrm{CP}$ content and vice versa.
The results also indicated that the metabolizable energy (ME) values as assessed in the present study were higher than the values $(9.3-10.7 \mathrm{MJ} / \mathrm{kg} \mathrm{DM})$ reported by Vellaikumar (2006); but, comparable with the values (13.2 $\mathrm{MJ} / \mathrm{kg} \mathrm{DM}$ ) reported by An et al. (2004). The IVDMD the silage in the present study was significantly higher than the values $(63.7-71.3 \%)$ reported by Vellaikumar (2006) but slightly lower than the values (85.6-88.2\%) reported by Gebregziabher (2013). This difference is probably related to the difference in ensiling methods (bucket versus sack) and ensiling process and management.

The NDF content was nearly comparable with values (20.8$25.4 \%$ ) reported by Gebregziabher (2013), but lower than the values (27.1-28.1\%) reported by Giang et al (2004). This difference could be attributed to the varietal differences and stage of maturity of the plant. The acid detergent fiber (ADF) and acid detergent lignin (ADL) values as observed in this study were within the range of the values (14.7-16.2\% and $2.7-4.9 \%$, respectively) reported by Gebregziabher (2013).

The dry matter content of the grass from the natural pasture increased towards the end of the experiment; because of dry season which led to faster maturity. The findings agree with earlier results (Tesfaye, 2008 and 33.8-91.6\% Dinku 2012) and contradict with the reports of Sisay (2008).

The crude protein (CP) content of the natural pasture as assessed in this study was higher than the values (6.0 and $6.6 \%$ ) reported by Sisay (2006) and Adugna (2008), respectively, but similar with toshe values (8.2-10.8\%) reported by Tesfaye (2008). However, the values are slightly lower than those values $(10.8-15.2 \%)$ reported by Dinku (2012). This may be attributed to the species composition differences and also due to the stages of maturity. In the present study NDF and ADF contents of the 
natural pasture were comparable with the report (66.9 and $38.8 \%$ for NDF and ADF, respectively) of Adugna (2008). Tesfaye (2008) also reported similar values $(60.76,73.9 \%$ and 40.30, 49.59\% for NDF and ADF, respectively) with the present study, the comma indicates to separate for two season values. The NDF (62.85-63.85\%) of natural pasture in present observation was slightly higher while ADF was comparable (30.24-30.83\%) but ADL was lower than (18.6$21.38 \%)$ the report of Dinku (2012). This might be due to differences in season and stages of maturity at the time of sampling and also due to species composition differences.

The IVDMD of the natural pasture grass was higher than the values $(43.2 \%)$ reported by Tesfaye (2008) but lower than values $(62 \%)$ reported by Adugna (2008). This may be attributed to the stage of maturity of the natural pasture, the season of sampling, and the species composition of grasses in the pastures. Zinash et al. (1995) also reported that the cell wall constituents of the plant are the most factors that affected the forage intake and digestibility.

\section{Nutrient intake of the experimental lambs}

As presented in (Table 2) DM and nutrient intakes increased with increasing levels of supplementation. The present observations are in accordance with the findings of Sniyders (1992). The results as obtained by Aregheore (2004) too indicated that there was improvement in feed intake as the levels of sweet potato vines increased with a basal diet containing batiki-grass (Ischaemum aristatum var. indicum). Similarly, Khalid et al. (2013) also observed that the feed intake of Nubian goats are higher in sweet potato vine than Sorghum vulgare and clitoria (Clitoria ternate) diets. However, the results of a study by Tadesse, Mengistu and Ajebu (2013) indicated that there was no significant differences in DM intake as the levels of sweet potato vine was increased in the diet of goats reared in Sidama zone. The study also indicated that there was no refusal in the supplementary diets indicating that the sweet potato silage was palatable as a livestock feed. As indicated by Zinash et al. (1995) the palatability of a feed can be associated with the cell wall constituents of the plant and these factors influence the forage intake and digestibility. Kariuki et al. (2001) also reported that inclusion of dismodium and sweet potato vine in the diets of steers fed a basal diet of Napier grass tended to increase intake and rumen degradation of all nutrients which could be due to increased availability of nitrogen to rumen microbes and enhanced rate of digestion (Adugna and Sundstøl, 2000).

The crude protein and metabolize energy intake increased significantly across the treatment groups, with higher values recorded among the lambs fed in T4 diet and the lowest among those fed on $\mathrm{T} 2$ diet. The difference may be attributed to increase in DM intake across the treatments. Preston and Leng (1987) also reported that ruminants increase their feed intake in response to an increase in demand for energy or protein or both them.
Growth performance and feed conversion ratio of the experimental lambs

The results from (Table 3 ) indicate that the average daily weight gain increased linearly with the levels of sweet potato silage supplementation, possibly due to linear increment in nutrient intake plus better digestibility of the sweet potato silage (due to low cell wall constituents and crude fiber) when compared to the natural pasture. Sweet potato vines alone can supply all the protein needed by fattening animals as recommended by Ravindran (1995).

The average daily weight gain (ADG) of lambs fed on T3 and T4 are higher than the values (20-60 g/day) reported by Kebede et al. (2008). The ADG for the lambs fed on T1 and $\mathrm{T} 2$ diet are within the range of values assessed by Kebede et al. (2008). The ADG for lambs fed on T1, T2 and T3 were similar to the values (36-82 g/day) observed by Aregheore (2004). The ADG for lambs fed on T4 are higher than the values (56.9-86.4 g/day) obtained by Olorunnisomo (2007) but $\mathrm{T} 2$ and $\mathrm{T} 3$ were within the range of values while $\mathrm{T} 1$ had lower values. Similarly, T3 and T4 in the present study had higher ADG values (44.2- $63.5 \mathrm{~g} / \mathrm{d}$ ) than the finding of Lam and Ledin (2004) but T1 and T2 were in the range of the values. The current findings are in close agreement with the findings of Dinku (2012) who reported better growth (up to $106 \mathrm{~g} / \mathrm{head} /$ day) in Arsi Bale sheep supplemented with sweet potato vines. However, ADG in this study were lower than the values of $165.6 \mathrm{~g} /$ day reported by Fikre (2009). The difference in ADG may be attributed to differences in the feeding system where some fed the vine as hay or silage others fed the vine with or without the root, which influence the balance between dietary energy and protein and thereby growth.

In the present study the feed conversion ratio (FCR) was inversely proportional to the level of supplementation of sweet potato silage (Table 3 ). This is probably related to the good condition of the grazing pasture had some contribution on the body weight gain of the experimental lambs where it could have provided sufficient amount of nutrients especially, crude protein and metabolizable energy.

The FCR in present study was better than the values (7.6 8.8) reported by Olorunnisomo (2007). Similarly, the current study FCR had better (5.7-6.9) than the finding of Lam and Ledin (2004). This indicates that preservation of sweet potato had a positive effect on the feed utilization efficiency of animals. Therefore, sweet potato was better used as preserved (silage) than as fresh in order to improve feed utilization and body weight gain of the animals. Moreover, Aregheore (2004) found improving trend of FCR from 23.6 to 12.5 by increasing the ratio of sweet potato vine to batiki-grass (Ischaemum aristatum var. indicum).

\section{Carcass traits of the experimental lambs}

Slaughter body weight (SBW) increased linearly with the levels of supplementation (Table 4) and supplemented groups had better SBW than those grazing alone. This might be attributed to better nutrient composition of the silage when compared to the pasture grass. These 
observations are in accordance with the findings of Tadesse, Mengistu and Ajebu (2013) and are comparable with the values (16.1 and $22.3 \mathrm{~kg}$ ) in the Haraghe highland sheep (Hirut, 2008). Lambs fed T1 and T2 had lower SBW than earlier report (20.1-24.4 kg) of Emebet (2008), while those fed T3 and T4 were within the rage of this values. Additional provision of supplementary crude protein and metabolizable energy had improved carcass weights. Similar results were reported where supplemented sheep had heavier carcass than non-supplemented one (Mulu, 2005). However, the results disagree with the study of Simret (2005); where no significant differences were observed among the supplemented with graded levels of peanut cake and wheat bran mixture supplementing of Somali goats.

Lambs fed T3 and T4 had higher hot carcass weight (HCW) than earlier report $(5.2-9.1 \mathrm{~kg}$ ) of Hirut (2008) but, $\mathrm{T} 1$ and $\mathrm{T} 2$ within the range, while it was comparable with the finding (8.0- 10.6kg) of Emebet (2008) and that (8.3$10.7 \mathrm{~kg}$ ) of Dinku (2012) who supplemented sweet potato vine to grazing sheep. Katongole et al. (2009) also indicated that animals (goats) supplemented with sweet potato vine had better hot carcass weight than those on scarlet eggplant (Solanum aethiopicum).

Dressing percentage (DP) in the present study followed similar trend as $\mathrm{HCW}$ because supplemented groups received more $\mathrm{CP}$ and energy than those on natural pasture alone and sweet potato vine had comparable CP content with concentrates. This idea is supported by Kebede et al. (2008); where no significant differences of dressing percentages were observed among Arisi-Bala goats when sweet potato vine substituted up to $100 \%$ of concentrates. The present study was comparable with the results of Dinku (2012) who reported up to $46 \%$ of dressing percentage by supplementing $204.7 \mathrm{gDM}$ sweet potato vine to grazing sheep. Katongole et al. (2009) also indicated that animals (goats) offered diets supplemented with sweet potato vine had better dressing percentage than scarlet eggplant (Solanum aethiopicum). Moreover, Mulu (2005) also reported that sheep supplemented with graded level of breweries' dried grain had higher dressing percentage as compared to non-supplemented sheep. The dressing percentage of lambs on T1 and T2 were similar but, T3 and T4 were greater than the values $(43.7-45.9 \%)$ reported by Kefyalew, Sandip and Yigrem (2013), for Arsi-Bale sheep reared under farmers' management system. However, the results of present study was lower than that of fat-tailed lambs (50.1-58.2\%) reported by Kashan et al. (2005). This difference could be related to either breed or feeding system of the sheep. Similar justification has been reported that feeding system affects carcass traits of goats; animals managed on poor quality feed had poor carcass yields (Legessee et al., 2006).

The present study of primal cuts of the experimental lambs were lower than the values $(4.6-5.2,3.4-4.0,3.3-3.9$ and 5.8-6.1; for shoulder and neck, racks, loins and legs respectively) reported earlier (Kashan et al., 2005). This attributed either to feeding system or breed difference. Moreover, Kebede et al. (2008) found acceptable results of carcass cuts (shoulder and neck, racks, loins and legs) in Arisi-Bala goats which increasing the ratio of sweet potato vine substituted to concentrates.

The current findings clearly showed that sweet potato silage supplementation had a positive effect on HCW, SBW, DP and carcass cuts. Many factors that affect the growth and carcass traits such as nutrition, age, sex, genetics, season and other related factors affect carcass evaluation (McDonald et al., 2002 and Taylor and Murray, 1991).

Some edible and non-edible offal of the experimental lambs

In the present study supplementing had significantly affected edible and non-edible offal's of the experimental lambs (Table 5). This idea was in line with earlier findings (Hirut, 2008; Emebet, 2008; Mulu, 2005). Tadesse, Mengistu and Ajebu (2013) also observed that supplementing of sweet potato vine had better edible and non-edible offal's than the grass hay diet fed alone. The present observation indicated that the level of supplementation had no significant effect on the weight change of testis. This study was in agreement with the finding of Mulu (2005); he was no significant difference in testis weight were observed for Fogera sheep. Emebet (2008) also found no significant difference in testis weight among the supplemented groups (mixtures of wheat bran and brewers dried grain) and not supplemented one. The heart weight of the current experimental animals was not significantly different in all the treatment groups. This indicates that supplementation had no effect on the heart weight change. Similar results were reported for supplemented and non- supplemented groups of black head Somali sheep (Emebet, 2008).

\section{CONCLUSION}

Supplementation of sweet potato silage to grazing lambs had a positive effect on growth performance, nutrient intake and carcass parameters (dressing percentage, slaughter body weight, hot carcass weight and primal carcass cuts of shoulder and neck, rack, loins and legs). The effects were more pronounced in the highest level of supplementation. This is because sweet potato silage had high in-vitro dry matter digestibility. All the parameters studied had significantly increased with increasing level of supplementation; except feed conversion ratio. Therefore, it is concluded that the lambs grazing on natural pasture are supplementing sweet potato silage up to $4 \%$ of their body weight on dry matter bases resulted in better feed intake, body weight gain, dressing percentage, slaughter weight, hot carcass weight and carcass cuts of shoulder and neck, rack, loins and legs. 


\section{ACKNOWLEDGMENT}

Authors would like to thank the International Potato Center (CIP) for all the financial supports given to conduct this research.

\section{REFERENCES}

[1] Abdullah, A.Y., Purchas, R.W., Davies, A.S., 1998. Patterns of change with growth for muscularity and other composition characteristics of Southdown rams selected for high and low back depth. N. Z. J. Agric. Res. 41, 367-376.

[2] Adugna Tolera and F. Sundstøl, 2000. Supplementation of graded levels of Desmodium intortum hay to sheep feeding on maize Stover harvested at three stages of maturity. Feed intake, digestibility and body weight change. Animal Feed Science and Technology. 85: 239-257.

[3] Adugna Tolera, 2008. Feed resources and feeding management: A manual for feed operators and development workers. Ethiopia Sanitary and Phytosanitary Standards and Livestock and Meat marketing Program (SPS-LMM). Hawassa University, Hawassa, Ethiopia.

[4] An.L. V., Tran Thi Thu Hong, Jan Erik Lindberg, 2004. Ileal and total tract digestibility in growing pigs fed cassava root meal diets with inclusion of fresh, dry and ensiled sweet potato (Ipomoea batatas L. (Lam.)) leaves. Animal Feed Science and Technology (114) 127-139.

[5] AOAC, Association of Official Analytical Chemists, 1990. Methods of analysis. INC.,Arlington, Virgina, USA.

[6] Aregheore E.M. 2004. Nutritive value of sweet potato (Ipomoea batatas (L) lam) forage as goat feed: voluntary intake, growth and digestibility of mixtures of sweet potato and batiki grass (Ischaemum aristatum var. indicum. Small ruminants Res.) 51: 235-241.

[7] CSA (Central Statistical Agency) of Ethiopia, 2013. Agricultural Sample Survey; Report on: Livestock and Livestock Characteristics. CSA, Federal Democratic Republic of Ethiopia, Addis Ababa, Ethiopia, vol.2, pp.194.

[8] Dinku Getu, 2012 .Nutritive value of natural pasture from gazing land, two varieties of sweet potato morphological fractions and effect of feeding sweet potato vine to gazing sheep. The MSc. Thesis Presented to the School of Graduate Studies of Hawassa University College of Agriculture, Ethiopia. 83p.

[9] Emebet Legesse, 2008. Supplementation of Blackhead Ogaden Sheep Fed Haricot Bean (Phaseolus vulgaris) Haulms with Mixtures of Wheat Bran and Brewers Dried Grain: Effects on Feed Utilization, Live Weight Gain and Carcass Parameters. The MSc. Thesis Presented to the School of Graduate Studies of Haramaya University, Ethiopia.69 p.
[10]Etela, U.I. OJI, G.A. Kalio and G.O. Tona , 2008. Studies on sweet potato forage and dried brewers' grains as supplements to green panic for Bunaji cows. Tropical Grasslands Volume 42, 245-251.

[11]Fikre Keba, 2009. sheep production system in Damot Gale District and supplement value of pigeon pea (Cajanus cajan) and sweet potato tuber (Ipomoea batatus) in sheep fattening diets M.Sc.Thesis University of Hawassa, Hwassa, Ethiopia.

[12] Gebreegziabher Zereu, 2013. Chemical composition and in vitro dry matter digestibility of fresh, dried and ensiled vines of sweet potato (Ipomoea batatas) cultivars. The MSc. Thesis Presented to the School of Graduate Studies of Hawassa university College of Agriculture, Ethiopia. 75p.

[13] Giang H.H, Le L.V, Ogle B., 2004. Digestibility of dried and ensiled sweet potato roots and vines and their effect on the performance and economic efficiency of F1 crossbred fattening pigs. Livestock Research for Rural Development. Vol. 16, Art. \#50. Retrieved,

from http://www.lrrd.org/lrrd16/7/gian16045htm.(Accessed on June,2013 ).

[14] Hirut Yirga, 2008. Supplementation of concentrate mix to Hararghe highland sheep fed a basal diet of urea-treated maize Stover: effect on feed utilization, live weight change and carcass characteristics Msc. Thesis Haramaya University.

[15] Kariuki J.N., S. Tamminga, C.K. Gachuiri, G.K. Gitau and J.M.K. Muia, 2001. Intake and rumen degradation in cattle fed napier grass (Pennisetum purpurium) supplemented with various levels of Desmodium intortum and Ipomoea batatus vines, South African J. of Anim. Sci.31(3):153-211

[16] Kashan N.E.J., Manafi Azar G.H., Afzalzadeh A., Salehi A. , 2005.Growth performance and carcass quality of fattening lambs from fat-tailed and tailed sheep breeds. Small Ruminant Research (60) 267-271.

[17] Katongole, C. B., Bareeba, F. B., Sabiiti, E. N., Ledin, I., 2009. Intake, growth and carcass yield of indigenous goats fed market wastes of sweet potato (Ipomoea batatas) vines and scarlet eggplant (Solanum aethiopicum). Tropical Animal Production and Health, Health, 41, 613 1623-1631.

[18] Kebede, T., Lema,T., Tadesse, E., and Guru, M., 2008. Effect of level of substitution of sweet potato (Ipomoea Batatas. L) Vines for concentrate on body weight gain and carcass characteristics of browsing Arsi-Bale goats. In: Journal of Cell and Animal Biology Vol. 2 (2), pp. 036-042. Available online at http://www.academicjournals.org/JCAB

[19] Kefyalew Berihun, Sandip Banerjee and Sintayrhu Yigrem, 2013.Carcass Traits of Arsi-bale Sheep and Goat Reared under Farmers Management System in Sidama Region of Southern Ethiopia. Middle-East Journal of Scientific Research 13 (11): 1465-1470. 
[20] Khalid A. F., Elamin K. M., Amin A. E., Tameem Eldar A. A., Mohamed M. E., Hassan H. E. and Mohammed M. D. ,2013. Effects of Using Fresh Sweet Potato (Ipomoea Batatas) Vines on Performance and Milk Yield of Lactating Nubian Goats. J Anim Sci Adv, 3(5): 226-232.

[21] Kung L. and Shaver R. ,2001. Interpretation and use of silage fermentation analysis reports. http://ag.udel.edu/departments/anfs/faculty/kung/articl es/interpretation_and_use_of_silage.htm. (Accessed on September, 2013)

[22] Lam V and Ledin I, 2004. Effect of feeding different proportions of sweet potato vines (Ipomoea batatas L.(Lam.)) and Sesbania grandiflora foliage in the diet on feed intake and growth of goats. Livestock Research for Rural Development. Vol. 16, Art. \#77. Retrieved August 24, 2016, from http://www.lrrd.org/lrrd16/10/lam16077.htm

[23] Legesse ,G.Abebe ,G. Goetsch,A. 2006.Performance and harvest measure of Somali and Arsi-Bale goats managed under three feeding system in Ethiopia .Journal of Applied Animal Research ,30,5-12.

[24] McDonald, P., A.R. Edwards, D.F.J. Greenhalgh, A.C. Morgan, 2002. Animal Nutrition. $6^{\text {th }}$ ed. Prentice Hall, London. Pp. 245-477.

[25] Mulu Moges, 2005. Effects of feeding different levels of breweries' dried grain on live weight gain and carcass characterstics of wogera sheep fed on hay basal diet. The MSc. Thesis Presented to the School of Graduate Studies of Haramaya University, Ethiopia.56 p.

[26] Olorunnisomo O. A. 2007. A cost-benefit analysis of sweet potato production for sheep feeding in the southwest of Nigeria. Livestock Research for Rural Development. Volume 19, Article \#80. http://www.lrrd.org/lrrd19/6/olor19080.htm (Accessed on July 2013).

[27] Preston, T.R., A.R. Leng, 1987. Matching ruminant production systes with available resources in the tropics and sub tropics. Penambul Books, Armidale. $245 p$.

[28] Ravindran V., 1995. Use of cassava and sweet potatoes in animal feeding. FAO (food and agriculture organization) Rome(Italy).

[29] Simret Betsha, 2005. Supplementation of graded levels of peanut cake and wheat bran mixtures on nutrient utilization and carcass parameters of Somali goats. An Msc. Thesis Presented to the School of Graduate Studies of Alemaya University Ethiopia. 75p.

[30] Sisay Amare, 2006. Qualitative and Quantitative Aspects of Animal Feed in Different Agroecological Areas of North Gonder. MSc. Thesis. Alemaya University ,Dire Dawa.

[31] Sniyders, Muia, J. \& Kariuki, J.K. 1992. Yield and quality of sweet potato vines harvested at different stages. KARI- Naivasha Research Report 1992. pp. 37.

[32] Solomon Gizaw, Azage Tegegne, Berhanu Gebremedhin and Dirk Hoekstra, 2010. Sheep and goat production and marketing systems in Ethiopia: Characteristics and strategies for improvement. IPMS (Improving Productivity and Market Success) of Ethiopian Farmers Project Working Paper 23. 58pp.

[33] Stathers, T., Namanda, S., Mwanga, R.O.M., Khisa, G., Kapinga, R., 2005. Manual for Sweet potato Integrated Production and Pest Management Farmer Field Schools in sub-Saharan Africa. International Potato Center, Kampala, Uganda. pp168 +xxxi. ISBN 9970-895-01

[34] Tadesse Megersa, Mengistu Urge, Ajebu Nurfeta, 2013. Effects of feeding sweet potato (Ipomoea batatas) vine as a supplementing on feed intake, growth performance, digestibility and carcass characteristics of Sidama goats fed a basal diet of natural grass hay. Tropical Animal health production 45:593-601.

[35] Taylor, S.T., J.I. Murray, 1991. Effect of feeding level, breed and milking potential on body tissues and organs of mature, non-lactating cows. Animal Production. 49: 385-409p.

[36] Tesfaye Desalew, 2008. Assessment of feed resources and rangeland condition in Metema district of North Gondar Zone, Ethiopia. M.Sc. Thesis of Haramaya University.

[37] Van Soest, P.J. and J.B. Robertson, 1991. Analysis of forage and fibrous foods. A laboratory manual for Animal science. 613 Cernell University, Ithaca, New York, USA.

[38] Vellaikumar S., Chung, I. B. . Prasad KVSV, Ravi D., Khan A. A. AND Blummel M.,2006. In vitro gas production technique for assessment of sweet potato (Ipomoea batatas (i) lam) silage using fresh faecal inoculum from pigs. International Livestock Research Institute, available on sweetpotatoknowledge.org/.../use.../silage/korea-2006paper-silage quality (Accessed November, 2013).

[39]Zinash Sileshi. 1995. Effect of harvesting stage on yield and quality of natural pasture in the Central high lands of Ethiopia. In Proceeding of the $3^{\text {rd }}$ Annual Conference of the Ethiopian Society of Animal Production (ESAP), Addis Ababa, Ethiopia. 